\title{
A razão das emoções: um ensaio sobre "O erro de Descartes"
}

O erro de Descartes: emoção, razão e o cérebro humano, de António R. Damásio ${ }^{1}$

\author{
Carlos Tomaz \\ Lilian G. Giugliano \\ Universidade de Brasília
}

$\mathrm{U}$

ltimamente, vários estudos têm abordado o "velho" tema das emoções e a sua importância no controle do comportamento,

incluindo as chamadas funções mentais superiores como a percepção, aprendizagem, memória e inteligência. Para aqueles, como nós, que trabalham com emoção e cognição é gratificante constatar que o debate sobre o tema atravessou a barreira dos laboratórios e da academia e passou a fazer parte do cotidiano de um público mais geral.

"O Erro de Descartes" de António Damásio é um livro elegante, de uma leitura arrebatedora, que ilustra o fato de que as emoções são indispensáveis para a nossa vida racional. São as emoções que nos fazem únicos, é o nosso comportamento emocional que nos diferencia uns dos outros. A natureza e a extensão do nosso repertório de respostas emocionais não depende exclusivamente do nosso cérebro, mas da sua interação com o corpo, e das nossas próprias percepções do corpo. Como diz Damásio, o corpo representado no cérebro constitui-se num quadro de referência indispensável para os processos neurais que nós experienciamos como sendo a mente.

Neste ponto, o autor aponta alguns "erros" de Descartes - a separação entre a mente e o corpo. $\mathrm{O}$ que se passa no cérebro são 
operações mentais; isto influencia o corpo e vice-versa. Entende-se, portanto, o título do livro. A mente é fruto do cérebro contrapondo o dualismo cartesiano no qual a alma (razão pura) é independente do corpo e das emoções, e não ocupa lugar no espaço. Além disso, o método de estudo mecanicista proposto por Descartes é questionado. Damásio defende uma fusão do estudo neurobiológico com a investigação psicológica numa abordagem integrativa das emoções e da razão. Pesquisas subdividindo o fenômeno nas menores partes possíveis a fim de se compreender cada uma em separado, como propôs Descartes no seu livro "Discurso do Método", não nos levariam a um entendimento completo e amplo da tomada de decisões ou de qualquer outro fenômeno.

O dualismo cartesiano tem influenciado o pensamento filosófico e a pesquisa científica, em particular a inteligência artificial. Segundo Damásio, a concepção de que a mente (entendida como processos cerebrais) é algo separado e/ou independente do corpo tem levado alguns pesquisadores a suporem que serão capazes de compreender o que somos biologicamente através da simulação de processos biológicos com computadores que só possuem uma "mente". Nesta abordagem não há espaço à idéia de um corpo modificável em certas circunstâncias que chamamos emoções e à apreciação do estado deste corpo e da mente durante as emoções. Apreciação esta a que Damásio se refere como os sentimentos.

Através da análise sistemática de casos clínicos e da experimentação neuropsicológica com animais de laboratório, António e sua esposa Hanna nos mostram como as emoções são indispensáveis na gênese e na expressão do comportamento. De acordo com Damásio, a interrelação entre as emoções e a razão remontam à historia evolutiva dos seres vivos. Durante a evolução natural o estabelecimento de respostas comportamentais adaptativas são moldadas por processos emocionais e a escolha de respostas em determinadas situações reflete o uso da razão. Ou seja, o estabelecimento de repertórios adaptativos seriam moldados pelas emoções e a seleção de comportamentos no futuro determinados pela razão.

A primeira parte do livro apresenta casos intrigantes de pessoas com lesões cerebrais. Um deles é o de de Phineas Gage que em 1848, 
teve a parte frontal do seu cérebro traspassada por uma barra de ferro e espantosamente não veio a falecer. Entretanto, depois deste acidente Gage passou a se comportar de uma maneira estranha. Ele que era uma pessoa responsável e trabalhadora, tornou-se imprevisível e com uma grande dificuldade em tomar decisões. Apesar disso, o seu raciocínio lógico, a sua memória consciente e habilidades lingüísticas encontravam-se normais. Outros casos posteriores que também apresentavam lesões do córtex frontal demonstravam uma incapacidade em tomar decisões. Uma análise neuropsicológica desses pacientes indicou uma baixa reatividade emocional. A partir desta observação o autor sugere o déficit no comportamento emocional como causa da dificuldade em tomar decisões racionais. Segundo ele, a razão, por si só, não sabe quando começar ou parar de avaliar custos e benefícios para uma tomada de decisão. É o quadro referencial das nossas emoções que seleciona as opções.

Neste ponto são feitos questionamentos sobre a influência das emoções na tomada de decisões, algo que nos parece tão racional. Será que no momento de decidir é a emoção que determina a resposta? Pode haver um comportamento puramente racional sem a influência da emoção?

Com essas questões levantadas, Damásio passa a apresentar uma série de argumentos anátomo-fisiológicos sobre a formação e processamento de imagens no cérebro e defende que o nosso raciocínio é feito de seqüências ordenadas de imagens. Esses dados apontam para uma íntima relação entre as estruturas cerebrais envolvidas na gênese e na expressão das emoções (o sistema límbico) e áreas do córtex cerebral ligadas à tomada de decisões (ex. córtex frontal).

A partir deste ponto Damásio introduz a hipótese do marcador somático, um dos objetivos centrais do livro. Esta hipótese é uma elaboração neuropsicológica da teoria da emoção de William James (1884). Segundo Damásio, existem emoções primárias e secundárias e sentimentos associados às emoções. As emoções primárias envolveriam disposições inatas para responder a certas classes de estímulo, controladas pelo sistema límbico. As emoções secundárias seriam aprendidas e envolveriam categorizações de representações de 
estímulos, associadas a respostas passadas, avaliadas como boas ou ruins. As estruturas do córtex cerebral seriam o substrato neural das emoções secundárias, mas a expressão dessas emoções também envolveria as estruturas do sistema límbico. Apesar desta interrelação, essas duas formas de emoção são distintas. Isto é evidenciado, por exemplo, pelo fato de um sorriso espontâneo ser diferente daquele intencional.

Os sentimentos seriam a experiência de tais mudanças associadas às imagens mentais da situação. Desta forma, a emoção esta intimamente associada à memória; ou seja, ao contexto em que é adquirida na experiência individual.

Existem evidências mostrando uma sobreposição dos substratos neurais subjacentes à memória e emoção ${ }^{2}$. Esta hipótese tem sido sustentada por experimentos conduzidos por Damásio e colaboradores demonstrando que pacientes com lesões do córtex frontal apresentam correlatos neurovegetativos quando experenciam uma emoção primária. Entretanto, eles não conseguem responder a imagens aterrorizantes, mesmo quando "sabem" que essas imagens deveriam pertubá-los. Mais intrigante ainda foi o resultado de experimentos em que esses pacientes demonstraram ser incapazes de se comportar racionalmente numa situação de jogo de apostas, terminando com perdas enormes de dinheiro. Ou seja, uma falha no julgamento de ações adequadas com relação ao futuro.

Por conseguinte, pessoas com déficits na integração das funções subjacentes ao córtex frontal e ao sistema límbico são incapazes de emoções secundárias, ou de aprendizagem emocional. Uma das contribuições importantes de Damásio e colaboradores tem sido revelar alguns dos substratos neurais envolvidos na aprendizagem emocional.

Pode-se afirmar que para uma vida normal não é suficiente reagir aos desafios do meio ambiente com emoções primárias. Da mesma forma, é contraprodutivo separar a razão da emoção. As emoções são uma parte indispensável da nossa vida racional. Assim, ao contrário do que propõe Descartes e mesmo Kant, que o raciocínio deve ser feito de uma forma pura dissociada das emoções, na verdade são as emoções que permitem o equilíbrio das nossas decisões. Como o pró- 
prio Damásio sugere, o único e verdadeiro Kantiano é um paciente com lesão no córtex pré-frontal.

Em conclusão, o livro de Damásio é emocionante! Uma referência indispensável para psicólogos, neurologistas e todos interessados no estudo do comportamento humano.

\section{Referências}

James, W. (1884). What is an emotion? Mind, 9, 188-204.

Tomaz, C., \& Graeff, F. G. (Orgs.) (1993). Emotion and memory. Behavioural Brain Research (vol. 58). Amsterdam: Elsevier.

Carlos Tomaz é professor do Instituto de Biologia, Departamento de Ciências Fisiológicas e Centro de Primatologia da Universidade de Brasília, Laboratório de Neurobiologia. Endereço para correspondência: Laboratório de Neurobiologia, UNB, C. Postal 04631, 70910-900, Brasília, DF. E-mail: ctomaz@unb.br. Lilian G. Giugliano é estudante do Curso de Biologia da Universidade de Brasília e bolsista do programa PETBiologia/CAPES/UnB.
${ }^{1}$ O Erro de Descartes: Emoção, Razão e o Cérebro Humano, de António R. Damásio (São Paulo: Companhia das Letras, 1996, ISBN 85-7164-530-2, 336 páginas, R\$ 26,50 (Tradução portuguesa do original Descartes' error: Emotion, reason and the human brain, Putnan Pub. Group, 1994, por Dora Vicente e Georgina Segurado).

${ }^{2}$ Algumas dessas evidências estão descritas em: Tomaz \& Graeff (1993, p. 216).

Sobre o autor 